\title{
Raf kinase inhibitor protein inhibits esophageal cancer cell invasion through downregulation of matrix metalloproteinase expression
}

\author{
DONGQIANG ZHAO ${ }^{1 *}$, JUNJI MA ${ }^{1 *}$, JUNLI SHI $^{1}$, LIJUAN CHENG $^{1}$, \\ FANGFANG $\mathrm{LI}^{2}$, XIAOYU JIANG ${ }^{3}$ and HUIQING JIANG ${ }^{1}$ \\ ${ }^{1}$ Department of Gastroenterology, The Second Hospital of Hebei Medical University, \\ Hebei Key Laboratory of Gastroenterology, Hebei Institute of Gastroenterology, Shijiazhuang, \\ Hebei 050000; ${ }^{2}$ Department of Biochemistry and Molecular Biology, Basic Medical College of \\ Hebei Medical University, Shijiazhuang, Hebei 050017, P.R. China; ${ }^{3}$ Department of Anatomy and \\ Cell Biology, Wayne State University School of Medicine, Detroit, MI 48201, USA
}

Received January 9, 2013; Accepted April 9, 2013

DOI: $10.3892 /$ or.2013.2464

\begin{abstract}
Esophageal cancer is the eighth most common malignant tumor in the world and is a common cause of tumor-related death. The development of esophageal cancer is a complex process involving many pathogenetic factors, multiple stages and accumulation of multiple gene mutations and interactions. This study aimed to investigate the effects of Raf kinase inhibitor protein (RKIP) on the proliferation, apoptosis and invasion of TE-1 esophageal cancer cells. Surgical specimens from esophageal cancer patients were classified into esophageal cancer tissues, tumor-adjacent tissues and normal esophageal tissues. The tissues were fixed in $4 \%$ paraformaldehyde solution for hematoxylin and eosin and immunohistochemical staining. RKIP expression in esophageal tissues was detected by immunohistochemical staining. The esophageal cancer cell line TE-1 was exposed to four different viruses: RKIP-RNAi-AD, NC-RNAi-GFP-AD, RKIP-AD and GFP-AD. Cell proliferation was detected by MTT assay and cell apoptosis was detected by flow cytometry. Cell invasion was determined by a Transwell coated with Matrigel. RKIP, phospho-RKIP, Raf-1, phospho-Raf-1, ERK1/2, phospho-ERK1/2, GRK-2 and GAPDH expression was assayed by western blotting. LIN28 and MMP-14 mRNA was assayed by qPCR. The results showed that RKIP expression was reduced in esophageal cancer tissues in comparison
\end{abstract}

Correspondence to: Professor Huiqing Jiang, Department of Gastroenterology, The Second Hospital of Hebei Medical University, No. 215 Heping West Road, Shijiazhuang, Hebei 050000, P.R. China E-mail: huiqingjiang@yahoo.com.cn

*Contributed equally

Key words: esophageal cancer, invasion, Raf kinase inhibitor protein, proliferation, apoptosis with expression in normal esophageal epithelium tissues and tumor-adjacent tissues. Reduced RKIP expression was associated with lymph node or distant metastasis in esophageal cancer. RKIP inhibited the invasive and metastatic abilities of esophageal cancer cell line TE-1 by downregulating mRNA expression of LIN28 and MMP-14. RKIP had no effect on the MAPK signaling pathway in the esophageal cancer cell line TE-1, but was involved in the $G$ protein-coupled signaling pathway. Our findings clearly demonstrate that RKIP inhibits esophageal cancer cell invasion by downregulating the expression of GRK-2, LIN28 and MMP-14.

\section{Introduction}

Esophageal cancer is a malignant tumor of the esophageal epithelial tissues, which occurs more frequently in males than in females and is traditionally more prevalent in subjects older than 40 years. However, in recent years there has been an increased tendency for the disease to appear at a younger age $(1,2)$. The pathological classification predominantly includes squamous cell carcinoma and adenocarcinoma, which account for over $95 \%$ of all cases. Squamous cell carcinoma is the more common of the two types. It has been estimated that $\sim 80 \%$ of all esophageal cancer cases occur in developing countries, with the majority of the cases being squamous cell carcinoma (2). However, the incidence of esophageal adenocarcinoma has been shown to be increasing in Western industrialized countries (3).

The development of esophageal cancer is a complex process involving many pathogenic factors, multiple stages, and accumulation of multiple gene mutations and interactions. These factors cause dysregulation of oncogenes, tumor-suppressor genes and signaling protein molecules at the molecular level (4).

Raf kinase inhibitor protein (RKIP) is a family of small, cytosolic phosphatidylethanolamine-binding proteins originally purified from bovine brain. This protein family is highly conserved and is rarely homologous to other types of proteins. RKIP is widely distributed in many tissues in various 
mammals such as mouse, monkey and human. It acts as a signal regulator, which not only inhibits Raf-mediated MAPK and ERK activities, but also inhibits the NF- $\kappa \mathrm{B}$ signaling pathway and regulates the activity of $G$ protein-coupled receptors (5-7).

Reduced RKIP expression has been shown to affect cell growth, angiogenesis, apoptosis and gene integrity (8). Our previous study found that RKIP may prevent liver fibrosis, which is a precancerous lesion, through its inhibition of hepatic stellate cell (HSC) proliferation (9). Increased RKIP expression was shown to suppress invasion and reduce metastasis to basilar membranes in mouse models of prostate cancer. It has also been shown to inhibit growth and invasion of ovarian cancer. Reduced RKIP expression is closely associated with progression and prognosis of hepatocellular carcinoma, colorectal cancer, gastric cancer and gastrointestinal stromal tumors (10-21). It has recently been proposed that reduced RKIP expression is also related to progression and pathological staging of esophageal cancer (22-24). However, the underlying mechanisms of RKIP in esophageal cancer cells remain unclear. The present study was, therefore, designed to investigate the mechanisms involved in RKIP esophageal cancer progression.

\section{Materials and methods}

Subjects. Surgical specimens from esophageal cancer patients were classified into esophageal cancer tissues, tumor-adjacent tissues ( $2 \mathrm{~cm}$ from the lesion) and normal esophageal tissues ( $5 \mathrm{~cm}$ from the lesion). The specimens were collected from the Department of Thoracic Surgery, The Second Hospital of Hebei Medical University. Patient gender and age, post-surgical pathological staging, lymph node status and distant metastasis were documented. The tissues were either fixed in $4 \%$ paraformaldehyde solution for hematoxylin and eosin (H\&E) and immunohistochemical staining, or were stored at $-80^{\circ} \mathrm{C}$ for western blotting analysis.

The study was approved by the Ethics Committee of The Second Hospital of Hebei Medical University. Informed consent was obtained from all participants following a detailed description of the purpose and potential benefits of the study.

Immunohistochemical staining. The tissues were cut into paraffin sections $(4-\mu \mathrm{m})$, dewaxed in xylene, dehydrated and high-pressure hot repaired in citrate buffer. The sections were incubated in $3 \%$ hydrogen peroxide and methanol at room temperature, and incubated in $1 \mu \mathrm{g} / 200 \mu \mathrm{l}$ of RKIP polyclonal antibody (Santa Cruz Biotechnology, Inc., Santa Cruz, CA, USA) [phosphate-buffered saline (PBS) was used in the negative controls] at $4^{\circ} \mathrm{C}$ overnight. The sections were then incubated in $50 \mu \mathrm{l}$ of polymer reinforcing agent at $37^{\circ} \mathrm{C}$ for $20 \mathrm{~min}$, incubated with $50 \mu \mathrm{l}$ of rabbit-on-mouse HRP-polymer (Santa Cruz Biotechnology, Inc.) at $37^{\circ} \mathrm{C}$ for $30 \mathrm{~min}$ and visualized using 3,3'-diaminobenzidine (DAB) for 3-5 min. Visualization was terminated with tap water. The sections were stained with hematoxylin, with a tan color indicating positive staining. Five fields of view at high magnification (x400) were randomly selected and observed, and the area of positive staining was measured. Image-Pro Plus version 6.0 software was used for analysis. The RKIP staining results were scored by a previously described method (23). The IHC score (0-300) was calculated as the product of the staining intensity (1, weak; 2 , moderate or 3 , strong expression) and the staining rate (percentage of positive cells in tissues, $0-100 \%$ ). Tissues with final scores exceeding the median score were determined to have high RKIP expression; tissues equal or below the median were determined as having downregulated RKIP expression. Correlations between RKIP expression and lymph node or distant metastases were investigated.

Cell culture and viral infection. The esophageal cancer cell line TE-1 was purchased from the Cell Resource Center, Shanghai Institutes for Biological Science of the Chinese Academy of Sciences (Shanghai, China). The TE-1 cells were incubated in RPMI-1640 medium containing 10\% fetal bovine serum (FBS), $100 \mu \mathrm{g} / \mathrm{ml}$ streptomycin, $100 \mathrm{IU} / \mathrm{ml}$ penicillin, $1 \mathrm{~mol} / 1 \mathrm{HEPES}$ and $4 \mathrm{mmol} / 1$ glutamine in $5 \% \mathrm{CO}_{2}$ at $37^{\circ} \mathrm{C}$. When $90 \%$ single-layer saturation density was achieved, the cells were digested with trypsin containing $0.5 \%$ EDTA and passaged at a ratio of 1:2. The cell culture solution was replaced after 24, and $48 \mathrm{~h}$ later the cells were re-passaged.

Recombinant adenovirus was reconstructed by Shanghai GeneChem Co. Ltd. (Shanghai, China). The TE-1 cells were exposed to four different viruses: RKIP-RNAi-AD (which carried adenoviral RNAi vector targeting RKIP); NC-RNAiGFP-AD (a control viral vector for RNAi without a specific target); RKIP-AD (a recombinant adenovirus carrying the RKIP gene and expressing GFP); GFP-AD (a control vector RKIP-AD expressing GFP). RPMI-1640 medium without serum and antibiotics was used as a control. The TE-1 cells were seeded onto plates at a $70 \%$ saturation density. They were synchronized with RPMI-1640 medium without serum and antibiotics for $24 \mathrm{~h}$ prior to treatment. The number of virus particles required was calculated as the cell count $\mathrm{x}$ multiplicity of infection (MOI). The cell surface was covered with RPMI-1640 medium without serum and antibiotics, and incubated at $37^{\circ} \mathrm{C}$ for $2 \mathrm{~h}$, with a further incubation for $46 \mathrm{~h}$ after addition of complete medium. GFP expression was observed under an inverted fluorescence microscope (Leica DMI3000 B microscope), and determined by flow cytometry (FCM) to identify the viral infection.

Determination of cell proliferation. TE-1 cells in an exponential growth phase were seeded onto 96 -well plates at a concentration of $5 \times 10^{4} / \mathrm{ml} / 200 \mu \mathrm{l}$ well. The cells were infected with adenovirus as detailed above. Six replicate wells were used for each group, with RPMI-1640 medium containing $2 \%$ FBS being used as a negative control. After infection for 24, 48, 72 and 96 h, $20 \mu \mathrm{l}$ of 3-(4,5-dimethylthiazol-2-yl)-2, 5-diphenyltetrazolium bromide (MTT; Sigma Chemical Co., St. Louis, MO, USA) was added to each well and incubated for $4 \mathrm{~h}$, followed by the addition of $150 \mu \mathrm{l}$ of dimethyl sulfoxide (DMSO). The absorbance of each well at $492 \mathrm{~nm}\left(\mathrm{~A}_{492}\right.$ value) was determined using a microplate reader, and the negative control well was adjusted to 0 . The results were expressed as the $\mathrm{A}_{492}$ value in the experimental group/ $\mathrm{A}_{492}$ value in the control group $\mathrm{x} 100 \%$.

Determination of apoptosis. TE-1 cells in an exponential growth phase were seeded onto 6-well plates at a concentration of $5 \times 10^{4} / \mathrm{ml}$. The cells were infected with virus for $48 \mathrm{~h}$, digested with trypsin without EDTA, and re-suspended in PBS 
Table I. Concentration of the primary antibodies.

\begin{tabular}{lc}
\hline Primary antibodies & Dilution \\
\hline RKIP & $1: 300$ \\
Phospho-RKIP (Ser 153) & $1: 300$ \\
GRK2 & $1: 300$ \\
Raf-1 & $1: 500$ \\
Phospho-Raf-1 (Ser 338/Tyr 341) & $1: 600$ \\
ERK1/2 & $1: 2000$ \\
Phospho-ERK1/2 (Thr 202/Tyr 204) & $1: 2000$ \\
GAPDH & $1: 1000$ \\
\hline
\end{tabular}

RKIP, Raf kinase inhibitor protein; GRK2, G-protein-coupled receptor kinase-2.

to adjust the concentration to $5 \times 10^{5} / \mathrm{ml}$. The cells were then centrifuged at $2,000 \mathrm{x} \mathrm{g}$ for $5 \mathrm{~min}$ at $4^{\circ} \mathrm{C}$, and the supernatant was removed. The re-suspension and centrifugation procedure was repeated twice. The cells were then re-suspended in $500 \mu 1$ of binding buffer, supplemented with $1 \mu \mathrm{l}$ of Annexin V-PE, and slightly mixed. Apoptosis was determined after incubation for 5 to $15 \mathrm{~min}$ at room temperature.

Detection of cell invasiveness. Matrigel (BD Biosciences, Franklin Lakes, NJ, USA) and 24-well Transwells were stored at $4^{\circ} \mathrm{C}$ overnight. A total of $50 \mu \mathrm{l}$ of dissolved Matrigel was evenly coated onto the bottom of the upper chamber of each Transwell. The coated Transwells were incubated at $37^{\circ} \mathrm{C}$ for at least $1 \mathrm{~h}$ in $5 \% \mathrm{CO}_{2}$. After interference for $48 \mathrm{~h}$, the cells were digested with pancreatin, centrifuged and re-suspended in RPMI-1640 medium containing $1 \%$ bovine serum albumin (BSA), adjusting the cell concentration to $5 \times 10^{5} / \mathrm{ml}$. The cell suspension $(200 \mu \mathrm{l})$ was added to the upper chamber of the Transwells, and $600 \mu 1$ of RPMI-1640 medium containing $10 \%$ FBS was added to the lower chamber. The Transwells were then incubated at $37^{\circ} \mathrm{C}$ for $48 \mathrm{~h}$ in $5 \% \mathrm{CO}_{2}$. The noninvasive cells on the upper chamber were lightly removed with cotton swabs, and the Transwell was inverted, and air-dried. Anhydrous ethanol $(600 \mu \mathrm{l})$ was added to the 24 -well plates, and the membranes were immersed in the well. After $30 \mathrm{~min}$, the Transwells were removed, air-dried, and rinsed three times in PBS for $10 \mathrm{~min}$. The cells were stained with crystal violet, counted and photographed.

Western blot analysis. Frozen tissue samples $(100 \mathrm{mg})$ were rinsed twice in iced PBS, transferred to the ampulla of the homogenate tubes, and cut into pieces. RIPA lysis buffer $(1 \mathrm{ml})$ was added to the tubes, and the tissues were prepared in the homogenate. The TE-1 cells were cultured at a concentration of $1 \times 10^{7} / \mathrm{ml}$, rinsed with iced PBS and centrifuged at $3,000 \times \mathrm{g}$ for $10 \mathrm{~min}$ at $4^{\circ} \mathrm{C}$. The supernatant was removed, and $100 \mu \mathrm{l}$ of modified RIPA lysis buffer was added to the sediment. The tube was shaken for $15 \mathrm{sec}$, and the cells were lysed on ice for $30 \mathrm{~min}$. The supernatant was collected, and the protein concentration was determined using the Bradford method.

Sodium dodecyl sulfate-polyacrylamide gel electrophoresis (SDS-PAGE) was performed with $80 \mu \mathrm{g}$ of protein per
Table II. RNA oligonucleotides and qRT-PCR primers.

\begin{tabular}{ll}
\hline $\begin{array}{c}\text { Target gene } \\
\text { RKIP }\end{array}$ & \multicolumn{1}{c}{ Primer sequence (5'-3') } \\
Sense & AGACCCACCAGCATTTCGTG \\
Antisense & GCTGATGTCATTGCCCTTCA \\
MMP-14 & \\
Sense & GCTGAGATCAAGGCCAATGT \\
Antisense & ATGTAGGCATAGGGCACCTC \\
LIN28 & \\
Sense & TCGGACTTCTCCGGGGCCAG \\
Antisense & GCTGGTTGGACACGGAGCCC \\
GAPDH & \\
Sense & GAACGGGAAGCTCACTGGCATGGC \\
Antisense & TGAGGTCCACCACCCTGTTGCTG \\
\hline
\end{tabular}

well. The gel was transferred to a PVDF membrane in an ice bath, and blocked in 5\% non-fat milk powder (for nonphosphorylated antibody) or 5\% BSA (for phosphorylated antibody) at room temperature for $2 \mathrm{~h}$.

The primary antibodies RKIP, phospho-RKIP, GRK2 and GAPDH (Santa Cruz Biotechnology, Inc.), Raf-1 and phosphoRaf-1 (Bioworld Technology Inc., St. Louis Park, MN, USA), ERK1/2 and phospho-ERK1/2 (Cell Signaling Technology, Inc., Beverly, MA, USA) were diluted with blocking solution (Table I) and incubated at $4{ }^{\circ} \mathrm{C}$ overnight. The secondary antibody, HRP-conjugated goat anti-rabbit IgG, was diluted with blocking solution, shaken and incubated at room temperature for $2 \mathrm{~h}$. Electrochemiluminescence (ECL) was added for visualization, and X-ray images were generated. The visualized band was scanned, and quantitative analysis was performed using NIH ImageJ version 1.38 software. GAPDH was used as an internal reference for RKIP, and RKIP served as an internal reference for phospho-RKIP.

Results were expressed as the percentage of the optical density (OD) of the target band in relation to the OD of the internal reference.

Quantitative RT-PCR assay. Approximately $1 \times 10^{7}$ of the wall-adherent TE-1 cells were rinsed with sterile iced PBS, and suspended in $1 \mathrm{ml}$ of PBS after being scraped with cell scrapers. The cell suspension was transferred to Eppendorf tubes, centrifuged at $3,000 \mathrm{x}$ g for $10 \mathrm{~min}$ at $4^{\circ} \mathrm{C}$, and the supernatant was removed. TRIzol $(1 \mathrm{ml})$ was immediately added to the cell sediment and shaken. RNA was extracted following the manufacturer's instructions. In brief, $2 \mu \mathrm{l}$ of RNA was added to $500 \mu \mathrm{l}$ of diethylpyrocarbonate (DEPC)treated water, and the OD of the RNA samples was measured at 280 and $260 \mathrm{~nm}$ on an ultraviolet spectrophotometer. RNA was reverse transcribed into cDNA, and quantitative RT-PCR was performed on an ABI StepOne Plus real-time PCR system device. GAPDH was used as an internal reference gene. Primers were designed and synthesized according to the gene sequence in GenBank (Table II). The SYBR-Green reaction system was used for quantitative RT-PCR assay, and the $\Delta \mathrm{Ct}$ 

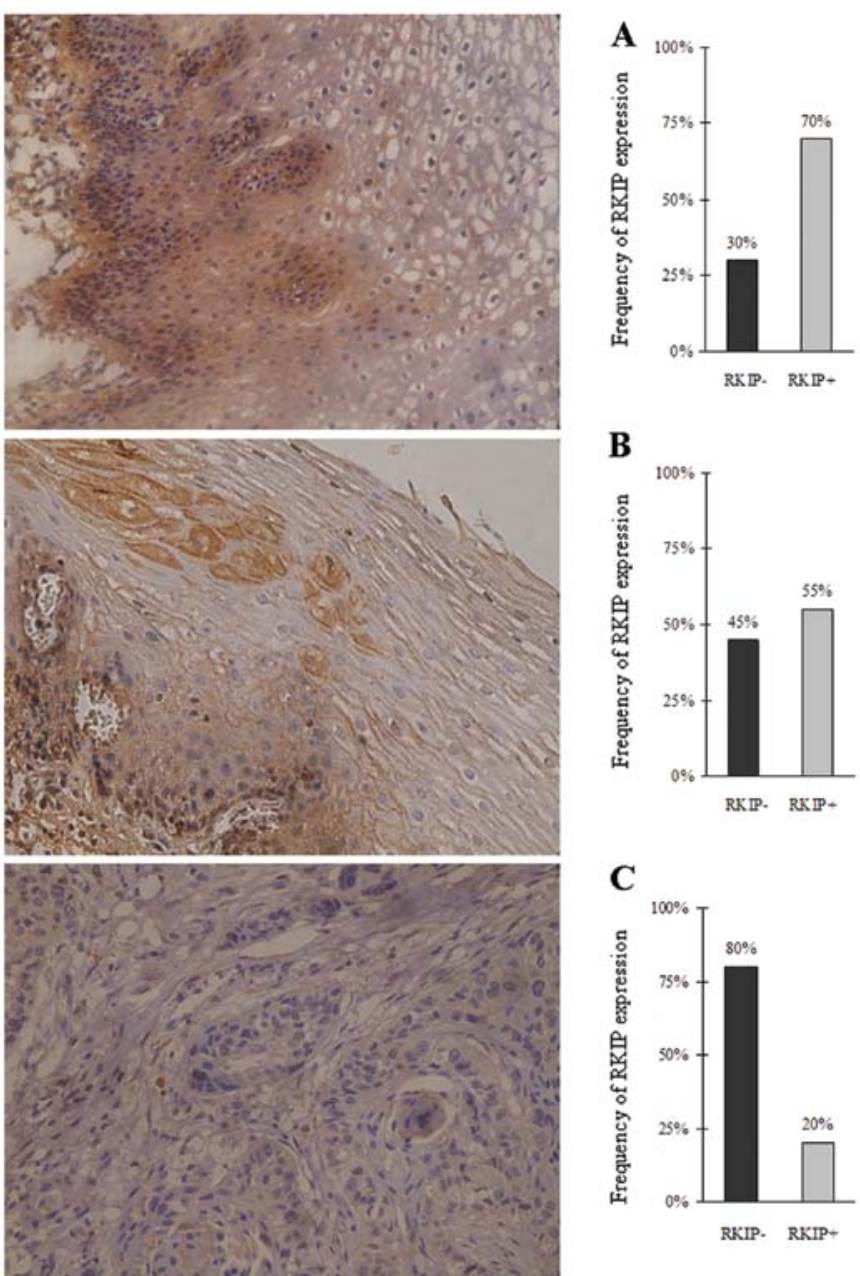

Figure 1. Esophageal tissues were immunostained with an anti-RKIP polyclonal antibody. Positive staining for Raf kinase inhibitor protein (RKIP) protein is indicated by a reddish-brown color. Abundant yellowish-brown particle sediments were observed in the cytoplasm of the basal, parabasal and superficial cells. RKIP immunoreactivity was detected in (A) normal and (B) peritumoral tissues (magnification, $\mathrm{x} 400$ ). A lower frequency of RKIP expression was observed in (C) the carcinoma tissues (magnification, $\mathrm{x} 400$ ). RKIP expression was significantly decreased in the esophageal cancer tissues.

value was calculated. Each reading was carried out in triplicate. The difference in mRNA gene expression was evaluated by relative quantification using the $2^{-\Delta \Delta \mathrm{Ct}}$ method. The mRNA expression of the gene in the blank vector control group was defined as 1 (the blank vector served as controls). The $2^{-\Delta \Delta \mathrm{Ct}}$ value indicated the relative mRNA expression of the target gene in the RKIP-RNAi-AD or RKIP-AD group.

Statistical analysis. Statistical analyses were performed using SPSS version 13.0. Data are expressed as the means \pm standard deviations (SD). The Chi-square, Kruskal-Wallis, Spearman, one-way analysis of variance (ANOVA), and Fisher's least significant difference (LSD) tests were used when appropriate. Values of $\mathrm{P}<0.05$ were considered statistically significant.

\section{Results}

Reduced RKIP expression in esophageal cancer tissues in comparison with normal esophageal epithelium tissues and
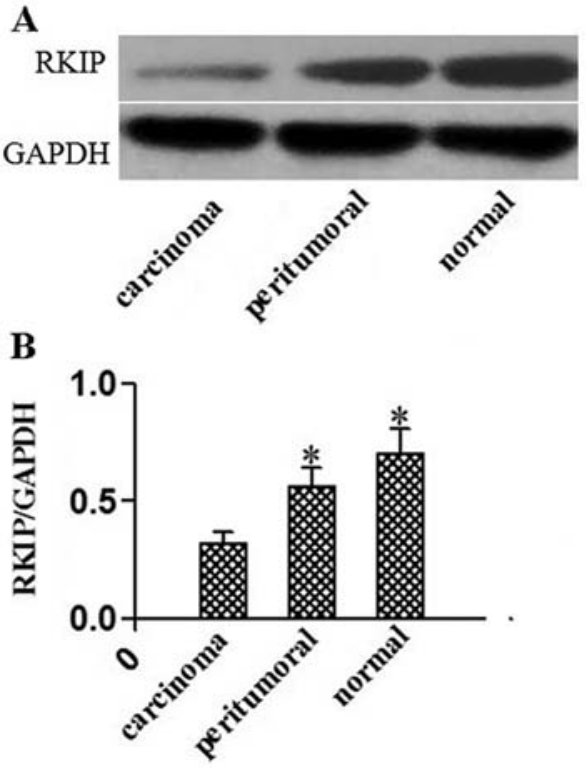

Figure 2. Expression of Raf kinase inhibitor protein (RKIP) in esophageal carcinoma tissues was detected by western blotting. RKIP expression was significantly reduced in the esophageal squamous cancer tissues when compared with that in the tumor-adjacent tissues and normal esophageal epithelia $\left({ }^{*} \mathrm{P}<0.05\right)$.

tumor-adjacent tissues. H\&E staining of the specimens from 40 patients with esophageal cancer was able to distinguish the specimens of esophageal squamous cell carcinoma, tumoradjacent tissues and normal squamous epithelium of the esophagus.

Immunohistochemical staining using the RKIP polyclonal antibody showed high RKIP expression in normal esophageal epithelia and tumor-adjacent tissues with abundant yellowishbrown particle sediments noted in the cytoplasm. RKIP expression was significantly lower in the esophageal squamous cell carcinoma cells with no obvious yellowish-brown particle sediments observed. The frequency of RKIP-positive expression was 70, 55 and $20 \%$ in the normal esophageal epithelia, tumor-adjacent tissues and esophageal squamous cell carcinoma cases, respectively (Fig. 1). These results indicate that the RKIP expression was significantly lower in the esophageal cancer tissues than that in the normal esophageal epithelia $(\mathrm{P}<0.05$, Chi-square test $)$.

Western blot analysis estimates of RKIP expression in the esophageal squamous cancer tissues, tumor-adjacent tissues and normal esophageal epithelia were $0.32 \pm 0.05,0.56 \pm 0.08$ and $0.70 \pm 0.11$, respectively, also indicating significantly reduced RKIP expression in the cancer tissues in comparison with the tumor-adjacent tissues and the esophageal epithelia $(\mathrm{P}<0.05$; Kruskal-Wallis test) (Fig. 2).

RKIP expression is associated with lymph node and distant metastasis of esophageal cancer. Immunohistochemical staining was performed to measure the mean density of the RKIP-positive staining in the cancer tissues. The mean rank of each parameter was calculated.

No correlation was observed between RKIP expression and gender, age or pathological tumor staging $(\mathrm{P}>0.05)$. Eleven of the 40 cases were well-differentiated carcinoma, 
Table III. Analysis of the clinicopathological parameters and RKIP expression.

\begin{tabular}{lrcc}
\hline $\begin{array}{l}\text { Clinicopathological } \\
\text { parameters }\end{array}$ & No. & Mean of rank & P-value \\
\hline $\begin{array}{l}\text { Gender } \\
\text { Male }\end{array}$ & 27 & 20.15 & 0.404 \\
$\quad$ Female & 13 & 21.13 & \\
Age (years) & & & \\
$>60$ & 22 & 19.97 & 0.388 \\
$\quad 60$ & 18 & 20.93 & \\
$\quad$ Pathological stage & & & \\
$\quad$ Stage I-II & 16 & 24.41 & 0.084 \\
$\quad$ Above stage II & 24 & 17.90 & \\
$\quad \begin{array}{l}\text { Tumor differentiation } \\
\quad \text { Well differentiated }\end{array}$ & 11 & 25.18 & 0.228 \\
$\quad \begin{array}{l}\text { Moderately differentiated } \\
\quad \text { Poorly differentiated }\end{array}$ & 21 & 19.69 & \\
$\quad$ Lymph node or distant & & 16.19 & \\
metastasis & & & \\
$\quad$ Metastasis & & & \\
$\quad$ Without metastasis & 25 & 15.96 & \\
\hline
\end{tabular}

RKIP, Raf kinase inhibitor protein.

21 were moderately differentiated carcinoma and 8 were poorly differentiated carcinoma. Multiple independent sample nonparametric testing resulted in mean ranks of 25.18, 19.69 and 16.19, respectively $(\mathrm{P}>0.05)$, demonstrating that RKIP expression was not associated with the degree of differentiation of esophageal cancer tissues (Table III). These results indicated low levels of RKIP expression in all 3 categories of tumor differentiation.

Fifteen of the 40 subjects had lymph node or distant metastasis. Independent two sample Mann-Whitney tests provided mean ranks of 11.4 and 15.96, respectively for patients with and without lymph node involvement or metastases $(\mathrm{P}<0.01)$, indicating that lower RKIP expression was associated with esophageal cancer metastasis (Table III). These findings further suggest that RKIP may act as a suppressor protein for metastasis.

RKIP has no effects on proliferation and apoptosis of the esophageal cancer cell line TE-1. The adenovirus infection efficiencies in the different groups were determined using flow cytometry. Adenovirus-mediated gene transfection at a MOI of 400 was employed for the subsequent experiments. MTT assay demonstrated that adenoviral infection for 24, 48,72 and $96 \mathrm{~h}$ had no effect on the viability of TE-1 cells ( $\mathrm{P}>0.05$ ) (Fig. 3A).

Flow cytometry revealed that there was no significant difference in the apoptotic rate of TE-1 cells between the RKIP-AD $(0.10 \pm 0.15 \%)$ and GFP-AD group $(0.11 \pm 0.25 \%$; $\mathrm{P}>0.05$ ) (Fig. 3B). Likewise, no significant difference was observed in the apoptotic rate of TE-1 cells between the
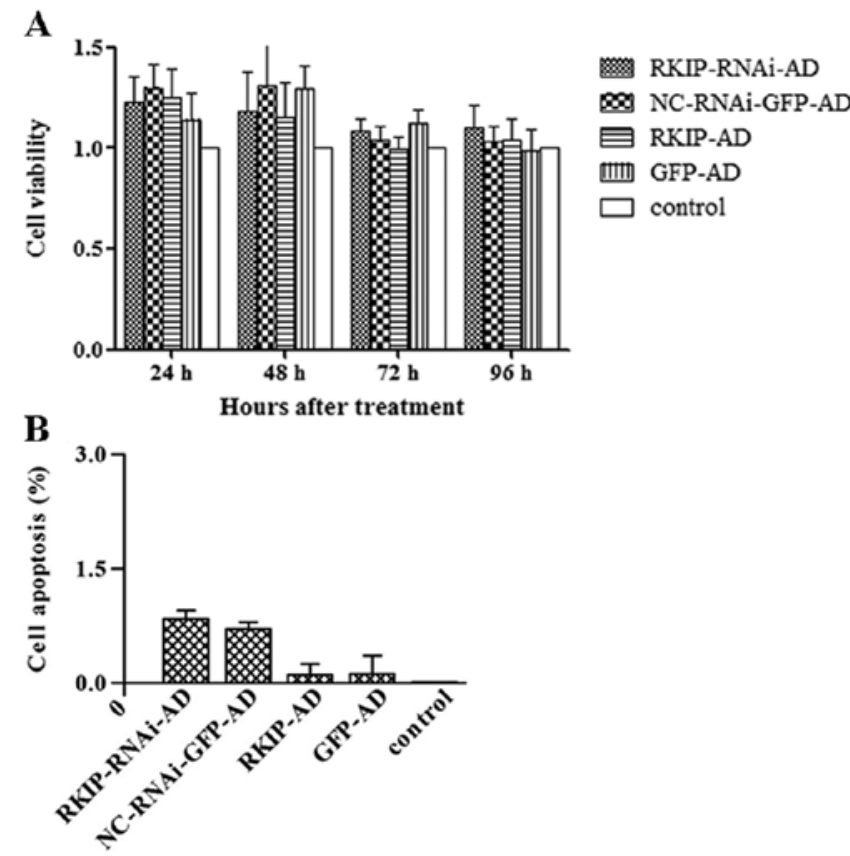

Figure 3. Effects of Raf kinase inhibitor protein (RKIP) on proliferation and apoptosis of the esophageal cancer cell line TE-1 were investigated. (A) Cell viability was assessed by MTT assay. Cell viability of TE-1 cells exposed to recombinant adenoviruses at different time points was shown. TE-1 cells were transfected with recombinant adenovirus for $24,48,72$ and $96 \mathrm{~h}$, respectively. TE-1 cells were infected with RKIP-RNAi-AD, NC-RNAi-GFP-AD, RKIP-AD and GFP-AD. Control cells were treated with RPMI-1640 only. No difference in cell viability was noted in the groups, $P>0.05$. (B) Apoptosis of TE-1 cells at $48 \mathrm{~h}$ after recombinant adenoviral infection as detected by PE labeled flow cytometry (FCM). Apoptosis of TE-1 cells transfected with RKIP-RNAi-AD, NC-RNAi-GFP-AD, RKIP-AD and GFP-AD, respectively, was detected by PE-labeled FCM. Control cells were treated with RPMI1640 only. No difference in apoptosis was noted among the groups, $\mathrm{P}>0.05$.

RKIP-RNAi-AD $(0.83 \pm 0.12 \%)$ and NC-RNAi-GFP-AD group $(0.70 \pm 0.10 \%$; P $>0.05)$ (Fig. 3B).

RKIP inhibits the invasive ability of the esophageal cancer cell line TE-1. The effect of RKIP expression on the invasive ability of esophageal cancer TE-1 cells was investigated (Fig. 4). The results showed that there were no significant differences in the invasive ability of TE cells among the GFP-AD $(80.25 \pm 10.87)$, NC-RNAi-GFP-AD (67.75 \pm 13.30$)$ and control (75.50 \pm 17.48 ; $\mathrm{P}>0.05$ ) groups. However, invasive potential was significantly higher in the RKIP-RNAi-AD group $(127.25 \pm 16.62)$ than that in the NC-RNAi-GFP-AD group (67.75 $\pm 13.30 ; \mathrm{P}<0.05)$, and the invasive ability was significantly lower in the RKIP-AD group $(9.50 \pm 7.14)$ than that in the GFP-AD group $(80.25 \pm 10.87$; $\mathrm{P}<0.05$ ) (Fig. 4).

RKIP has no effect on the MAPK signaling pathway in esophageal TE-1 cells, but is involved in the G proteincoupled signaling pathway. Western blot analysis was performed to determine the expression of RKIP and its phosphorylation (p-RKIP) level in TE-1 cells following treatment with the adenoviruses. The results showed that RKIP expression was significantly higher in the RKIP-AD group $(2.31 \pm 0.36)$ than that in the GFP-AD group $(0.43 \pm 0.09$; $\mathrm{P}<0.05$ ), and was significantly lower in the RKIP-RNAi-AD 

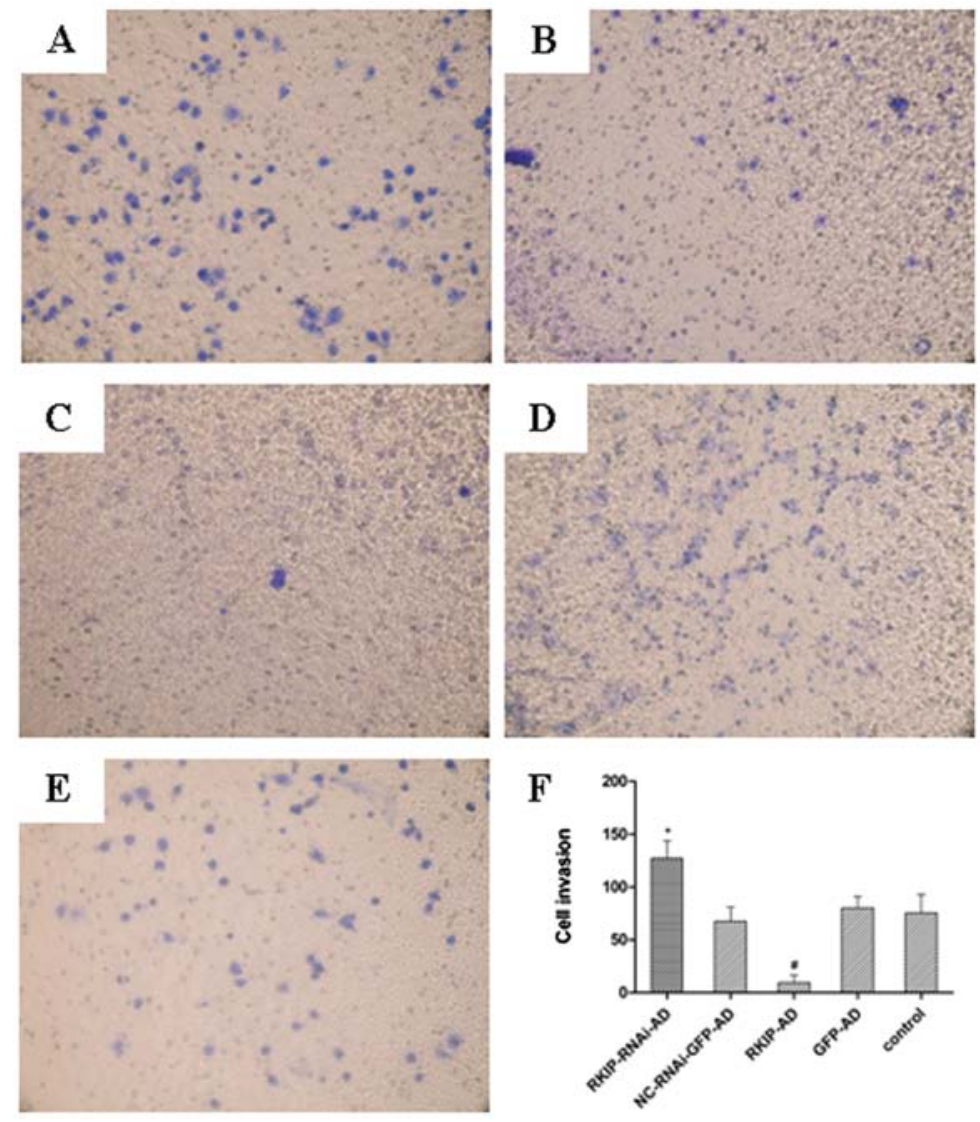

Figure 4. Invasive ability of TE-1 cells at $48 \mathrm{~h}$ after recombinant adenoviral infection as detected by the invasion assay (magnification, $\mathrm{x} 200)$. TE-1 cells were infected with (A) RKIP-RNAi-AD, (B) NC-RNAi-GFP-AD, (C) RKIP-AD and (D) GFP-AD, respectively. (E) TE-1 cells not infected with any vectors were used as the control. (F) The result showed that Raf kinase inhibitor protein (RKIP) inhibited the invasive ability of TE- 1 cells. "P<0.05 compared with the NC-RNAi-GFP-AD group. ${ }^{~} \mathrm{P}<0.05$ compared with the GFP-AD group.

A

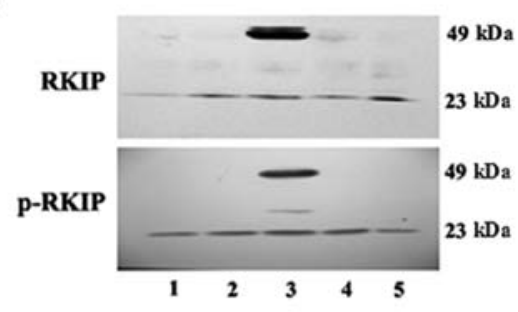

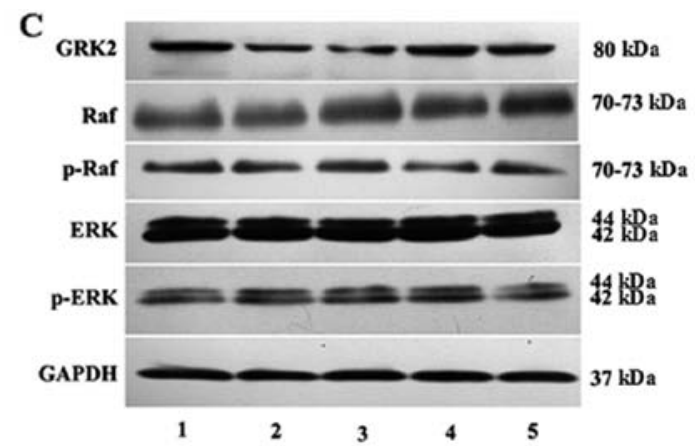

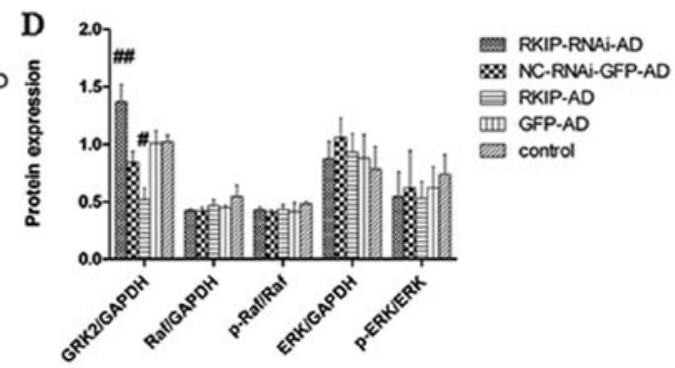

Figure 5. Western blot analysis was used to detect Raf kinase inhibitor protein (RKIP), p-RKIP, Raf, p-Raf, ERK, p-ERK, GRK2 and GAPDH protein expression in TE-1 cells at $48 \mathrm{~h}$ after adenoviral infection. Lane 1, RKIP-RNAi-AD; lane 2, NC-RNAi-GFP-AD; lane 3, RKIP-AD; lane 4, GFP-AD and lane 5, control group. In the RKIP-AD group, a large amount of RKIP was expressed as an exogenous protein ${ }^{* *} \mathrm{P}<0.05$ compared with the GFP-AD group). At the same time, RKIP expression was decreased in the RKIP-RNAi-AD group ( ${ }^{*} \mathrm{P}<0.05$ compared with the NC-RNAi-GFP-AD group). However, there were no differences in p-RKIP expression among the groups (A and B). GRK2 expression was increased in the RKIP-RNAi-AD group and decreased in the RKIP-AD group $\left({ }^{\# \#} \mathrm{P}<0.05\right.$ compared with the NC-RNAi-GFP-AD group; ${ }^{~} \mathrm{P}<0.05$ compared with the GFP-AD group). No differences in ERK, $\mathrm{p}$-ERK, Raf and $\mathrm{p}$-Raf were noted among the groups $(\mathrm{C}$ and $\mathrm{D})$. 

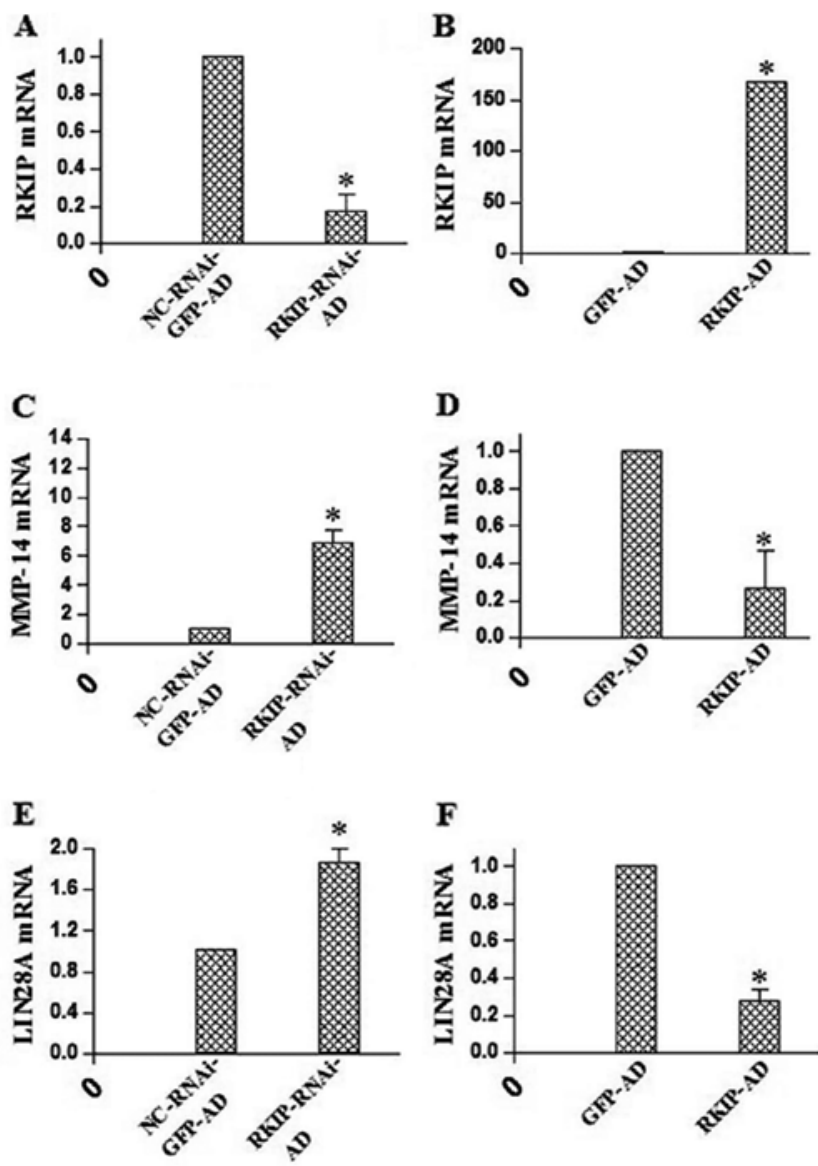

Figure 6. Effect of Raf kinase inhibitor protein (RKIP) RNAi and overexpression on the mRNA expression of RKIP, MMP-14 and LIN28 in the TE-1 cells. RKIP, MMP-14, and LIN28 mRNA expression was quantitated by real-time PCR. The expression was normalized as a ratio using GADPH as a housekeeping gene. A value of 1 for this ratio was arbitrarily assigned to the data obtained from the control. (A) RKIP mRNA expression was significantly suppressed in the RKIP-RNAi-AD group ("P<0.01). (B) RKIP mRNA expression was significantly increased in the RKIP-AD group $\left({ }^{*} \mathrm{P}<0.01\right)$ Expression of (C) MMP-14 and (E) LIN28 transcripts was increased by RKIP RNAi ("P<0.01). Expression of (D) MMP-14 and (F) LIN28 transcripts were significantly reduced in the RKIP-AD group ( $\left({ }^{*} \mathrm{P}<0.01\right)$. Comparisons in $\mathrm{A}, \mathrm{C}$ and $\mathrm{E}$ were made between TE-1 cells transfected with RKIP-RNAi-AD and those transfected with the vector NC-RNAi-GFP-AD. Comparisons in B, $\mathrm{D}$ and $\mathrm{F}$ were made between TE-1 cells transfected with RKIP-AD and those transfected with the vector GFP-AD. All data are expressed as means \pm SD from 3 individual experiments $(n=3)$.

group $(0.05 \pm 0.18)$ than that in the NC-RNAi-GFP-AD group $(0.38 \pm 0.08 ; \mathrm{P}<0.05)$. However, there was no significant difference in the $\mathrm{p}-\mathrm{RKIP} / \mathrm{RKIP}$ level between the groups $(\mathrm{P}>0.05)$ (Fig. 5A and B).

In contrast, GRK2 expression was significantly lower in the RKIP-AD group $(0.52 \pm 0.10)$ than that in the GFP-AD group $(1.01 \pm 0.11 ; \mathrm{P}<0.05)$, and was significantly higher in the RKIP-RNAi-AD group $(1.37 \pm 0.15)$ than that in the NC-RNAi-GFP-AD group $(0.84 \pm 0.10 ; \mathrm{P}<0.05)$. However, there was no significant difference in Raf, p-Raf, ERK and p-ERK expression between the groups $(\mathrm{P}>0.05)$ (Fig. 5C and D).

RKIP inhibits the invasive and metastatic ability of esophageal cancer cell line TE-1 by downregulating $m R N A$ expression of LIN28 and MMP-14. After increasing or inhibiting RKIP expression, quantitative RT-PCR was performed, and the mRNA expression of MMP-14, RKIP, LIN28 and GAPDH in the different groups was compared using the relative quantitative method. RKIP mRNA expression was significantly higher in the RKIP-AD group (166.46 \pm 0.09$)$ than that in the GFP-AD group $(\mathrm{P}<0.01)$, and was significantly lower in the RKIP-RNAi-AD group $(0.17 \pm 0.09)$ than that in the NC-RKIP-RNAi-AD group $(1.00 \pm 0.00 ; \mathrm{P}<0.01)$. The mRNA expression of MMP-14 was significantly lower in the RKIP-AD group $(0.26 \pm 0.20)$ than that in the GFP-AD group $(1.00 \pm 0.00 ; \mathrm{P}<0.01)$, and the mRNA expression of MMP-14 was significantly higher in the RKIP-AD group $(6.89 \pm 0.84)$ than that in the GFP-AD group $(1.00 \pm 0.00$; $\mathrm{P}<0.01)$. In addition, mRNA expression of LIN28 was significantly lower in the RKIP-AD group $(0.28 \pm 0.06)$ than that in the GFP-AD group $(1.00 \pm 0.00 ; \mathrm{P}<0.01)$, and was increased in the RKIPRNAi-AD group $(1.86 \pm 0.12)$ when compared with that in the NC-RKIP-RNAi-AD group $(1.00 \pm 0.00 ; \mathrm{P}<0.01)$ (Fig. 6).

\section{Discussion}

Esophageal cancer is the eighth most common malignant tumor in the world and the sixth most common cause of tumor-related death. The incidence of esophageal cancer has continued to increase during the last three decades $(1,25)$. In addition, there is regional variation in the incidence of esophageal cancer with an incidence of $\sim 40$ cases/100,000 in Western countries compared with an incidence of 50-100 cases/100,000 in China and South Africa $(26,29)$.

RKIP is a regulator protein which is involved in many signaling pathways where it mediates cell proliferation, apoptosis and metastasis in order to regulate cell proliferation balance. The present study demonstrated that RKIP expression was reduced in esophageal cancer tissues in a manner that was independent of gender, age, degree of tumor differentiation and pathological tumor stage. However, we also demonstrated that reduced RKIP expression was associated with an increased occurrence of lymph node and distant metastases, suggesting that it may be closely related with the invasive capacity of esophageal cancer cells. Other studies have also shown that downregulation of RKIP expression is related to regional lymph node metastasis and tumor stage (22-24). The critical role of RKIP in tumor metastasis was first identified in metastatic prostate cancer tissues. It was shown that RKIP expression was lower in metastatic prostate cancer than in primary tumor cells. Based on these findings, blood levels of RKIP are used as a prognostic marker for the malignant potential of prostate cancer. Other studies have shown that RKIP expression is downregulated in metastatic lymph nodes associated with human breast and metastatic colon cancer, further suggesting that downregulation of RKIP expression is involved in tumor metastasis. It has also been shown that overexpression of RKIP is associated with reduced vascular invasion in prostate cancer and melanoma. RKIP has also been reported to inhibit tumor invasion, and significantly reduced RKIP expression has been detected in insulinoma, colorectal carcinoma, hepatocellular carcinoma and ovarian cancer (30-34).

In the present study, an adenovirus overexpressing RKIP and a viral RNAi vector of RKIP was used to interfere with RKIP expression in esophageal cancer cells in order to investigate the role of RKIP in proliferation, apoptosis and invasion 
of esophageal cancer cells. RKIP expression had no effect on the proliferation and apoptosis of esophageal cancer cells. However, in vitro overexpression of RKIP significantly inhibited the invasive capacity of esophageal cancer cells.

Invasion is the most important phenotype of malignant tumors, and it is the major factor that determines the prognosis of malignant tumors. Specific microRNAs (miRNAs), including Let-7, have been reported to play a role in the maintenance of the invasiveness of cancer cells. It has been demonstrated that Let-7 degrades target genes and inhibits their transcription. In this way it functions at both the gene and protein levels to promote tumor metastasis.

Increased RKIP expression has been shown to promote Let-7 expression by inhibiting the MAPK signaling transduction pathway, and thereby preventing cell invasion and metastasis $(31,35)$. When cells are stimulated by extracellular grow th factors, activated Ras activates Raf-1 which in turn activates the MAPK signaling pathway. Subsequent activation of ERK1/2 promotes Myc expression and further promotes LIN28 expression. LIN28 inhibits Let-7 expression resulting in elevated expression of its target gene HMGA1, thereby activating genes such as Snail, Twist and Slug which promote cell invasion and metastasis. In the present study, we showed that RKIP overexpression inhibited the invasiveness of esophageal cancer cells and significantly reduced LIN28 transcription, suggesting that RKIP inhibited esophageal cancer cell invasion by downregulating LIN28 expression.

For tumors to develop, the normal cellular homeostasis of the microenvironment is destroyed and is replaced by one that facilitates tumor cell growth. The presence of inflammatory cytokines in the tumor microenvironment also plays a critical role in tumor invasion (36-39). Thus, maintaining the tumor microenvironment is a prerequisite for protecting or promoting the occurrence and development of tumors.

It has been shown that RKIP prevents the invasion of cancer cells by controlling the expression of matrix metalloproteinases (MMPs), particularly MMP-1 and MMP-2 (40). Silencing RKIP expression results in a highly invasive phenotype of the cancer cells with dramatically elevated levels of MMP-1 and MMP-2 expression, whereas overexpression of RKIP decreases cancer cell invasion in vitro and reduces MMP-1 and MMP-2 expression. In accordance with this finding, MMP-1 or MMP-2 in RKIP-knockout cells reverts their invasiveness and metastastic potential to normal levels (40). In the present study, we demonstrated that overexpression of RKIP significantly inhibited MMP-14 expression, indicating that it reduced the invasiveness of esophageal TE-1 cancer cells by downregulating MMP-14 expression. RKIP is a natural suppressor of Raf, which inhibits Raf phosphorylation, thereby inhibiting the MAPK signaling transduction pathway. It has been found that RKIP is highly expressed in Merkel cell carcinoma cells, but the MAPK signaling transduction pathway is not activated. These results indicate that RKIP does not affect the ERK/MAPK signaling transduction pathway or proliferation or apoptosis in Merkel cells.

In our studies with esophageal TE-1 cancer cells, overexpression or low expression of RKIP for $24 \mathrm{~h}$ resulted in stabilization of the MAPK signaling pathway, and either inhibition or activation of the $G$ protein-coupled signaling pathway. $G$ protein is a transmembrane protein, which acts as a second messenger, converting extracellular information to intracellular information. G-protein-coupled receptor kinase-2 (GRK-2) is therefore a negative feedback inhibitory protein for $\mathrm{G}$ protein-coupled receptors (GPCRs). GRK-2 has been shown to phosphorylate GPCRs, and separate G protein from GPCRs.

Protein kinase $\mathrm{C}$ (PKC) has been shown to phosphorylate RKIP at serine 153. Phosphorylated RKIP dissociates from Raf-1, binds to GRK-2 and inhibits its activity (6). The binding conversion from Raf-1 to GRK-2 suggests that RKIP serves as a signal regulator. In other words, after PKC is activated, RKIP is phosphorylated, becomes dissociated from Raf-1, and thereby prevents the inhibition of the ERK signaling pathway and associated increases in cell permeability. In this way it facilitates the binding of RKIP to GRK-2, resulting in activation of the $G$ protein-coupled signaling pathway. It can, therefore, be hypothesized that RKIP acts as a key that switches from one signaling pathway to another, depending on its degree of phosphorylation.

In conclusion, our findings clearly demonstrate that reduced RKIP expression is related to the development of lymph nodes or distant metastasis associated with esophageal cancer. We also provide evidence to suggest that RKIP inhibits esophageal cancer cell invasion by downregulating the expression of GRK-2, LIN28 and MMP-14.

\section{Acknowledgements}

This study was supported in part by grants to H.Q.J. from the Natural Science Foundation of Hebei Province (China, C2010000530), the Hebei Province Science and Technology Project financed by the Department of Finance, and a grant to D.Q.Z. from the Hebei Medical Research Key Project (China, 20110088), and a grant to J.J.M. from the National Natural Science Foundation of China (81200311).

\section{References}

1. Klein CA and Stoecklein NH: Lessons from an aggressive cancer: evolutionary dynamics in esophageal carcinoma. Cancer Res 69: 5285-5288, 2009.

2. Mao WM, Zheng WH and Ling ZQ: Epidemiologic risk factors for esophageal cancer development. Asian Pac J Cancer Prev 12: 2461-2466, 2011.

3. Lepage C, Rachet B, Jooste V, Faivre J and Coleman MP: Continuing rapid increase in esophageal adenocarcinoma in England and Wales. Am J Gastroenterol 103: 2694-2699, 2008.

4. Tew WP, Kelsen DP and Ilson DH: Targeted therapies for esophageal cancer. Oncologist 10: 590-601, 2005.

5. Yeung K, Seitz T, Li S, Janosch P, McFerran B, Kaiser C, Fee F, Katsanakis KD, Rose DW, Mischak H, Sedivy JM and Kolch W: Suppression of Raf-1 kinase activity and MAP kinase signalling by RKIP. Nature 401: 173-177, 1999.

6. Yeung KC, Rose DW, Dhillon AS, Yaros D, Gustafsson M, Chatterjee D, McFerran B, Wyche J, Kolch W and Sedivy JM: Raf kinase inhibitor protein interacts with NF-kappaB-inducing kinase and TAK1 and inhibits NF-kappaB activation. Mol Cell Biol 21: 7207-7217, 2001.

7. Deiss K, Kisker C, Lohse MJ and Lorenz K: Raf kinase inhibitor protein (RKIP) dimer formation controls its target switch from Raf1 to G protein-coupled receptor kinase (GRK) 2. J Biol Chem 287: 23407-23417, 2012.

8. al-Mulla F, Bitar MS, Taqi Z, Rath O and Kolch W: RAF kinase inhibitory protein (RKIP) modulates cell cycle kinetics and motility. Mol Biosyst 7: 928-941, 2011

9. Ma J, Li F, Liu L, Cui D, Wu X, Jiang X and Jiang H: Raf kinase inhibitor protein inhibits cell proliferation but promotes cell migration in rat hepatic stellate cells. Liver Int 29: 567-574, 2009. 
10. Keller ET: Role of Raf kinase inhibitor protein in pathophysiology of prostate cancer. For Immunopathol Dis Therap 2: 89-94, 2011.

11. Khamis ZI, Iczkowski KA and Sang QX: Metastasis suppressors in human benign prostate, intraepithelial neoplasia, and invasive cancer: their prospects as therapeutic agents. Med Res Rev 32: 1026-1077, 2012.

12. Bevilacqua E, Frankenberger CA and Rosner MR: RKIP suppresses breast cancer metastasis to the bone by regulating stroma-associated genes. Int J Breast Cancer 2012: 124704, 2012.

13. Granovsky AE and Rosner MR: Raf kinase inhibitory protein: a signal transduction modulator and metastasis suppressor. Cell Res 18: 452-457, 2008.

14. Klysik J, Theroux SJ, Sedivy JM, Moffit JS and Boekelheide K: Signaling crossroads: the function of Raf kinase inhibitory protein in cancer, the central nervous system and reproduction. Cell Signal 20: 1-9, 2008.

15. Zeng L, Imamoto A and Rosner MR: Raf kinase inhibitory protein (RKIP): a physiological regulator and future therapeutic target. Expert Opin Ther Targets 12: 1275-1287, 2008.

16. Wang J, Yang YH, Wang AQ, Yao B, Xie G, Feng G, Zhang Y, Cheng ZS, Hui L, Dai TZ, Du XB and Wang D: Immunohistochemical detection of the Raf kinase inhibitor protein in nonneoplastic gastric tissue and gastric cancer tissue. Med Oncol 27: 219-223, 2010 .

17. Chatterjee D, Sabo E, Tavares R and Resnick MB: Inverse association between Raf kinase inhibitory protein and signal transducers and activators of transcription 3 expression in gastric adenocarcinoma patients: implications for clinical outcome. Clin Cancer Res 14: 2994-3001, 2008.

18. Zlobec I, Baker K, Minoo P, Jass JR, Terracciano L and Lugli A: Node-negative colorectal cancer at high risk of distant metastasis identified by combined analysis of lymph node status, vascular invasion, and Raf-1 kinase inhibitor protein expression. Clin Cancer Res 14: 143-148, 2008.

19. Minoo P, Zlobec I, Baker K, Tornillo L, Terracciano L, Jass JR and Lugli A: Loss of raf-1 kinase inhibitor protein expression is associated with tumor progression and metastasis in colorectal cancer. Am J Clin Pathol 127: 820-827, 2007.

20. Al-Mulla F, Hagan S, Behbehani AI, Bitar MS, George SS, Going JJ, García JJ, Scott L, Fyfe N, Murray GI and Kolch W: Raf kinase inhibitor protein expression in a survival analysis of colorectal cancer patients. J Clin Oncol 24: 5672-5679, 2006.

21. Zlobec I, Baker K, Terracciano L, Peter S, Degen L, Beglinger C and Lugli A: Two-marker protein profile predicts poor prognosis in patients with early rectal cancer. Br J Cancer 99: 1712-1717, 2008.

22. Kim HS, Won KY, Kim GY, Kim SC, Park YK and Kim YW: Reduced expression of Raf-1 kinase inhibitory protein predicts regional lymph node metastasis and shorter survival in esophageal squamous cell carcinoma. Pathol Res Pract 208: 292-299, 2012.

23. Birner P, Jesch B, Schultheis A and Schoppmann SF: RAF-kinase inhibitor protein (RKIP) downregulation in esophageal cancer and its metastases. Clin Exp Metastasis 29: 551-559, 2012.

24. Gao C, Pang L, Ren C and Ma T: Prognostic value of raf kinase inhibitor protein in esophageal squamous cell carcinoma. Pathol Oncol Res 18: 471-477, 2012.
25. Bray F, Jemal A, Grey N, Ferlay J and Forman D: Global cancer transitions according to the Human Development Index (2008-2030): a population-based study. Lancet Oncol 13: 790-801, 2012.

26. Lambert R, Saito H, Lucas E and Sankaranarayanan R: Survival from digestive cancer in emerging countries in Asia and Africa. Eur J Gastroenterol Hepatol 24: 605-612, 2012.

27. Bosetti C, Levi F, Ferlay J, Garavello W, Lucchini F, Bertuccio P, Negri E and La Vecchia C: Trends in oesophageal cancer incidence and mortality in Europe. Int J Cancer 122: 1118-1129, 2008.

28. Brown LM, Devesa SS and Chow WH: Incidence of adenocarcinoma of the esophagus among white Americans by sex, stage, and age. J Natl Cancer Inst 100: 1184-1187, 2008.

29. Shibata A, Matsuda T, Ajiki W and Sobue T: Trend in incidence of adenocarcinoma of the esophagus in Japan, 1993-2001. Jpn J Clin Oncol 38: 464-468, 2008.

30. Woods Ignatoski KM, Grewal NK, Markwart SM, Vellaichamy A, Chinnaiyan AM, Yeung K, Ray ME and Keller ET: Loss of Raf kinase inhibitory protein induces radioresistance in prostate cancer. Int J Radiat Oncol Biol Phys 72: 153-160, 2008.

31. Yun J, Frankenberger CA, Kuo WL, Boelens MC, Eves EM, Cheng N, Liang H, Li WH, Ishwaran H, Minn AJ and Rosner MR: Signalling pathway for RKIP and Let-7 regulates and predicts metastatic breast cancer. EMBO J 30: 4500-4514, 2011.

32. Zaravinos A, Bizakis J and Spandidos DA: RKIP and BRAF aberrations in human nasal polyps and the adjacent turbinate mucosae. Cancer Lett 264: 288-298, 2008.

33. Li HZ, Gao Y, Zhao XL, Liu YX, Sun BC, Yang J and Yao Z: Effects of raf kinase inhibitor protein expression on metastasis and progression of human breast cancer. Mol Cancer Res 7: 832-840, 2009.

34. Li HZ, Wang Y, Gao Y, Shao J, Zhao XL, Deng WM, Liu YX, Yang $J$ and Yao Z: Effects of raf kinase inhibitor protein expression on metastasis and progression of human epithelial ovarian cancer. Mol Cancer Res 6: 917-928, 2008.

35. Dangi-Garimella S, Yun J, Eves EM, Newman M, Erkeland SJ, Hammond SM, Minn AJ and Rosner MR: Raf kinase inhibitory protein suppresses a metastasis signalling cascade involving LIN28 and let-7. EMBO J 28: 347-358, 2009.

36. Akutsu $\mathrm{Y}$ and Matsubara $\mathrm{H}$ : The significance of lymph node status as a prognostic factor for esophageal cancer. Surg Today 41: 1190-1195, 2011.

37. Sgourakis G, Gockel I, Lyros O, Lanitis S, Dedemadi G, Polotzek U, Karaliotas C and Lang H: The use of neural networks in identifying risk factors for lymph node metastasis and recommending management of $\mathrm{t} 1 \mathrm{~b}$ esophageal cancer. Am Surg 78: 195-206, 2012.

38. Ben-Neriah Y and Karin M: Inflammation meets cancer, with $\mathrm{NF}-\kappa \mathrm{B}$ as the matchmaker. Nat Immunol 12: 715-723, 2011.

39. Bromberg J and Wang TC: Inflammation and cancer: IL-6 and STAT3 complete the link. Cancer Cell 15: 79-80, 2009.

40. Beshir AB, Ren G, Magpusao AN, Barone LM, Yeung KC and Fenteany G: Raf kinase inhibitor protein suppresses nuclear factor- $\kappa \mathrm{B}$-dependent cancer cell invasion through negative regulation of matrix metalloproteinase expression. Cancer Lett 299: 137-149, 2010. 